\title{
DŁUG PUBLICZNY W POLSCE - INSTYTUCJONALNE MOŻLIWOŚCI JEGO REDUKCJI
}

\begin{abstract}
Streszczenie
W Polsce od czasu rozpoczęcia transformacji gospodarczej w 1989 roku mamy do czynienia z ciagle narastającym (w niektórych latach gwałtownie) długiem publicznym. Jest to bardzo niebezpieczne z punktu widzenia funkcjonowania państwa, ponieważ może doprowadzić do jego niewydolności finansowej. To negatywne zjawisko spowodowane reformami gospodarczymi, a w ostatnich latach wpływem światowego kryzysu finansowego oraz rosnących potrzeb budżetu państwa wymusza na sprawujących władzę dokonywanie zmian o charakterze instytucjonalnym (wprowadzanie nowych „reguł gry”) mających na celu ograniczanie wzrostu zadłużenia czy też jego redukcję. Niniejszy artykuł został poświęcony analizie wielkości długu publicznego w Polsce w latach 2000-2013. W pracy wskazano także na instytucjonalne możliwości ograniczania długu publicznego. Taki potencjał tkwi przede wszystkim w prowadzeniu odpowiedzialnej polityki fiskalnej (transparentnej, skutecznej, efektywnej itd.). W przekonaniu autorów tekstu działania w tym zakresie mogą znacząco wpłynąć na osiagnięcie stabilizacji w sektorze finansów publicznych w naszym kraju.
\end{abstract}

Słowa kluczowe: dług publiczny, deficyt budżetowy, procedura budżetowa, reguły fiskalne, niezależne instytucje fiskalne

\section{PUBLIC DEBT IN POLAND: INSTITUTIONAL CAPACITY FOR REDUCTION}

\section{Summary}

Ever since the beginning of the economic transformation in 1989, Poland has been struggling with constantly (and rapidly in certain years) growing public debt. This is very dangerous from the point of view of the functioning of the state and might lead to financial failure. This negative phenomenon, caused by economic reforms and in recent years the impact of the global financial crisis, forces governments to make changes of institutional nature (the introduction of new "game rules") aiming to curb debt growth or reduce its levels. This paper is focused on the analysis of the size of the public debt in Poland in the period 20002013. The authors also identify several institutional possibilities to limit the public debt. This potential lies primarily in a responsible fiscal policy (transparent, efficient, effective, etc.). The authors believe that action in this area can significantly contribute to the achievement of stability in the public finances of our country.

Key words: public debt, budget deficit, budget procedure, fiscal rules, independent fiscal institutions

DOI: 10.15290/ose.2015.01.73.14

1 Mgr Jakub Połomka - Wydział Ekonomii i Zarządzania Uniwersytetu w Białymstoku; e-mail: j.polomka@uwb.edu.pl; dr Marian Zalesko - Wydział Ekonomii i Zarządzania Uniwersytetu w Białymstoku; mail:mzalesko@uwb.edu.pl. 


\section{Wstęp}

Współcześnie dług publiczny stanowi problem większości krajów opartych na gospodarce rynkowej. Tę kategorię ekonomiczną powszechnie określa się jako całość finansowych zobowiązań władz publicznych z tytułu nadwyżki wydatków ponad osiagane dochody. Na świecie w ostatnim okresie mamy do czynienia z lawinowym przyrostem długu publicznego. Kwestia długu publicznego pojawiła się w latach dziewięćdziesiątych XX wieku również w krajach przechodzących transformację ustrojowa, w tym w Polsce. Stała się efektem zaburzeń w sferze finansów publicznych towarzyszących przeobrażeniom gospodarczym.

Niedobór w budżecie państwa w wymiarze poważnie zagrażającym reformom gospodarczym w Polsce pojawił się już w 1990 roku, na trwale wpisując się w realia naszej gospodarki. Od 2000 roku mieliśmy do czynienia z bardzo dynamicznym wzrostem długu publicznego. Olbrzymi jego przyrost odnotowano w latach 2007-2011 w okresie światowego kryzysu finansowego, uznawanego za największe przesilenie gospodarcze od czasu „wielkiej depresji”. Poza negatywnym oddziaływaniem kryzysu finansowego, na wielkość długu publicznego w Polsce wpływały coraz większe potrzeby budżetu państwa.

W artykule ukazano wielkość długu publicznego w Polsce w latach 2000-2013. Za początek analizy przyjęto 2000 rok ze względu na to, że wówczas rozpoczęto ewidencję długu publicznego, będącego wynikiem niezbilansowanych budżetów: rządowego i samorządowego (wcześniej kompleksowo ewidencjonowano tylko dług budżetu państwa). Celem opracowania była również próba ukazania rozwiązań instytucjonalnych, które mogły wywierać wpływ na ograniczenie długu publicznego. Szczególne miejsce w tej analizie zajęły nowe „reguły gry” związane z wdrażaniem odpowiedzialnej polityki fiskalnej.

\section{Współczesne rozumienie długu publicznego}

Dług publiczny nie jest novum w ekonomii. Ze studiów historii myśli ekonomicznej wynika, że korzenie długu publicznego jako kategorii ekonomicznej sięgają XIII wieku. Pierwsze wzmianki na temat długu pojawiły się w rozważaniach scholastyków, zwłaszcza w opracowaniach św. Tomasza z Akwinu. Bardziej doniosłe prace $\mathrm{z}$ tego zakresu zostawili merkantyliści i kameraliści (XVI-XVIII wiek). W XVIII wieku rozpoczął się okres, kiedy rozważania na temat długu publicznego stały się bardziej powszechne (teorie klasyków ekonomii). Należy tutaj wymienić prace: Davida Hume, Adama Smitha, Davida Ricardo, Johna Stuarta Milla czy też Jeana Baptiste Saya. Interesujące analizy z tego zakresu prowadzili również neoklasycy: Henry C. Adams, Charles F. Bastable oraz Paul Leroy-Beaulieu. Istotnym głosem $\mathrm{w}$ dyskusji na temat długu publicznego były także publikacje myśli interwencjonistycznej, m.in.: Adolfa Wagnera, Johna Maynarda Keynesa oraz postkeynesistów: Alvina H. Hansena czy Abby P. Lernera. Bardzo ważne analizy dotyczące długu publicznego prowadzili monetaryści z Miltonem Friedmanem na czele oraz Jamesem M. Buchananem, twórcą teorii wyboru publicznego. 
Współcześnie w literaturze ekonomicznej, zwłaszcza z zakresu finansów publicznych, oraz w aktach prawnych można odnaleźć wiele określeń długu publicznego. Okazuje się, że nie istnieje jednolite jego rozumienie. Jest tak zarówno w kwestii definicyjnej, jak i obliczeniowej.

Poniatowicz podkreśla, że niektóre definicje długu publicznego kłada akcent na podmioty zobowiązań, inne na przyczyny ich powstawania lub formy, w jakich są one zaciagane. Zwraca również uwagę na fakt, że nie udało się dotychczas ustalić jednego, powszechnie uznawanego w teorii ekonomii, ale i w polityce gospodarczej bezpiecznego poziomu zadłużenia [Poniatowicz, 2005, s. 27-30].

W literaturze amerykańskiej (w podręcznikach do ekonomii) można odnaleźć następujące definicje długu publicznego. Samuelson i Nordhaus piszą że zadhużenie państwa (niekiedy nasywane dtugiem publicynym) sktada sie z tacznych, csyli nagromadzonych po:syczek zaciqgnietych przez rzad lub inaczej dług publiczny stanowi catkowita wartość pienieżna zobowriqzań państwa [Samuelson, Nordhaus, 2012, s. 641]. Z kolei McConnell, Brue, Flynn pisza, że dług publiczny zasadniczo jest całością zakumulowanych (nagromadzonych) przez rząd deficytów w określonym czasie [McConnell, Brue, Flynn, 2009, s. 619].

W Unii Europejskiej mamy do czynienia z dwiema definicjami długu publicznego. Pierwsza znajduje się w Rosporzadzeniu Rady z.22 listopada 1993 roku w sprawie stosowania protokotu w spranie procedury dla nadmiernego deficytu zataczonego do Traktatu ustananiajacego Wspólnote Europejskeq (WE nr 3605/93), [Ro:porzadzenie Rady (WE), nr 3605/93]. Jest ona konsekwencja ustaleń zawartych w Traktacie ₹. Maastricht. Natomiast druga została sformułowana $\mathrm{w}$ ramach europejskiego systemu rachunków narodowych i regionalnych - ESA'95 [Ro:porzadzenie Rady (WE), nr 2223/96].

Dług publiczny, zgodnie z postanowieniami Traktatu ustanawiajacego Wspólnote Europejskeq, stanowi podstawę do wyliczenia jednego z dwóch budżetowych kryteriów konwergencji, a definiowany jest jako całkowity dług brutto w wartości nominalnej występujący na koniec roku i skonsolidowany dla sektora publicznego, obejmującego władze centralne, lokalne oraz fundusze ubezpieczeń społecznych. W skład opisywanego długu wchodza pozycje gotówki i depozytów, papierów wartościowych innych niż akcje oraz pożyczki [Rosporzadzenie Rady (WE), nr 3605/93].

Dług, zgodnie z ESA'95, różni się od przytoczonej wcześniej definicji dwoma zagadnieniami. Po pierwsze, szersza struktura, ponieważ zobowiązania, według metodologii ESA'95, obejmują dodatkowo pozycje z tytułu akcji i innych udziałów, rezerw techniczno-ubezpieczeniowych oraz pozostałych kwot do zapłacenia. Skutkuje to tym, iż w wartościach brutto wskaźnik ten charakteryzuje się wyższym poziomem niż dług według definicji traktatowej. Po drugie, formą wyceny - zobowiązania systemu rachunków narodowych i regionalnych są wyceniane w sposób rynkowy [Rosporząqzenie Rady (WE), nr 2223/96].

W polskiej literaturze dług publiczny jest określany w następujący sposób. Owsiak tę kategorię definiuje jako: finansowe zobowriqzanie władz publicznych (panstwonych $i$ samorzqdowych) z tytutu zaciagniecia pożyczek, pray caym najważniejsza praycryna powstawania dtugu jest zaciaganie pos̀yczele na sfinansowanie deficytu budżetowego [Owsiak, 2013, s. 330]. Natomiast Wernik pisze, że $w$ sensie ekonomicznym dlug publiczny może być interpretowany jako skumulowana suma deficytón seletora finansón publicznych z presesżości [Wernik, 2014, s. 112]. Szersze rozu- 
mienie długu publicznego proponuje E. Chojna-Duch, która określa go jako: łaczne finansowe zobowiazania jednostek sektora publicznego z. tytulu zróznicowanych z. ekonomicznego i prawnego punktu widzenia zdarzeń prawno-finansowych, a przede ws zystkim - niedoborón powstajacych w wyniku finansowania nadwyzki wydatków publicznych ponad dochody publiczne skumulowane w poprzednich okeresach; zobowiazania te poninny unvigledniać ich konsolidacje cryll eliminagje wrajemnych prepplywów finansonych miedsy nimi [Chojna-Duch, 2012, s. 273-274].

Bardzo wymowna definicja długu publicznego jest dostępna w Encyklopedii PWN, to: catkowita kwota zobowiqzan podmiotón sektora finansów publicznych (w szcrególności Skarbu Państwa), jednostek samorzadu terytorialnego ora funduszón celonych wobec wierzycieli zarónno krajonych (dtug publiczny krajony), jak i zagranicznych (dtug publiczny zagraniczny), ustalona po dokonaniu konsolidacij, tzn. po uyeliminowaniu wrajemnych zobowiazan tych podmiotón [Encyklopedia PWN...].

W Polsce dług publiczny został zdefiniowany w Ustawie ₹ dnia 27 sierpnia 2009 roku o finansach publicznych (Dz. U. Nr 157, poz. 1240 z późniejszymi zmianami). Rozumiany jest jako nominalne zadłużenie podmiotów sektora finansów publicznych, ustalone po wyeliminowaniu przepływów pomiędzy podmiotami należącymi do tego sektora. Obejmuje zobowiązania sektora finansów publicznych z tytułu:

a) wyemitowanych papierów wartościowych, opiewających na wierzytelności pieniężne;

b) zaciągniętych kredytów i pożyczek;

c) przyjętych depozytów;

d) wymagalnych zobowiązań:

- $\quad$ wynikających z odrębnych ustaw oraz prawomocnych orzeczeń sądów lub ostatecznych decyzji administracyjnych;

- $\quad$ uznanych za bezsporne przez właściwa jednostkę sektora finansów publicznych będącą dłużnikiem.

Jako kategoria ekonomiczna, dług publiczny wzbudza ekscytację zarówno wśród badaczy tego zjawiska, jak i ogólnie w społeczeństwie. Piszą o tym, w słynnym na całym świecie podręczniku do ekonomii, amerykańscy ekonomiści: P. A. Samuelson oraz W. D. Nordhaus w następujący sposób: Nie zapominajcie nigdy, że dtug publiczny wžbudz̨a

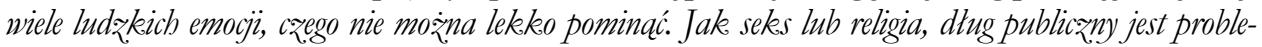
mem, o którym wssyscy lubimy dyskutować. Wielu ludzi przepowiadato koniec swiata, gdy dtug osiagnat jedna setna, jedna driesiata çyy jedna piata swego drisiejszego poziomu: każdego roku, kiedy to okropne nieszrczeście nie nadchodzito, ponawiali swe przeponiednie na nastepne lata [Samuelson, Nordhaus, 1997, s. 548].

Emocje dotyczące kwestii długu publicznego wynikają z istnienia dwóch, skrajnie sprzecznych ze soba, ideologii na temat jego istoty. W przekonaniu ekonomistów nurtu liberalnego ciagle rosnący dług publiczny jest symptomem niesprawnie funkcjonującego systemu finansów publicznych i jest szkodliwy dla całej gospodarki oraz państwa (tzw. ortodoksyjna teoria długu publicznego). Z kolei ekonomiści nurtu interwencjonistycznego uważają że państwo w celu stymulowania wzrostu i rozwoju gospodarczego powinno zadłużać się, a dług publiczny uważają za jedno z możliwych narzędzi ingerencji państwa w gospodarkę (tzw. interwencjonistyczna teoria długu publicznego). Zaprezentowana odmienność myślenia nie sprzyja dyskusji i sprecyzowaniu znaczenia długu 
publicznego w gospodarce. Tymczasem okazuje się, że dług publiczny to powszechne zjawisko w wielu krajach na świecie, również w Polsce.

\section{Kształtowanie się długu publicznego w Polsce w zarysie}

Historia długu publicznego w Polsce sięga okresu gospodarki centralnie kierowanej. Pojawił się on w latach siedemdziesiątych XX wieku w związku z zaciaganiem pożyczek zagranicznych. Jego rozmiary wzrosły w latach osiemdziesiątych ubiegłego stulecia na skutek ograniczonego dostępu do nowych kredytów. Wówczas narastanie długu wynikało z kapitalizacji niezapłaconych odsetek oraz naliczania odsetek karnych przez wierzycieli. Wymienione uwarunkowania sprawiły, że na początku lat dziewięćdziesiątych XX wieku nasz kraj był obciążony długiem odpowiadającym 95\% PKB, przy czym większość tego zadłużenia stanowiły zobowiązania wobec wierzycieli zagranicznych (w 1990 roku dług krajowy wynosił około $12 \%$ PKB, zagraniczny niespełna $83 \%$ ).

Od początku okresu transformacji trudnej sytuacji w zakresie zadłużenia zagranicznego towarzyszyło szybkie narastanie krajowego długu publicznego. Podstawowym jego źródłem były kumulujące się deficyty budżetu państwa oraz przejmowanie przez budżet zobowiązań powstałych przed rokiem 1989 (m.in. z tytułu zadłużenia zagranicznego), a także wzrost kosztów spłaty zadłużenia wewnętrznego, które powstało na skutek emisji skarbowych papierów wartościowych (np. obligacji).

Wymiary długu publicznego w Polsce w latach dziewięćdziesiątych XX wieku przedstawiono w tabeli 1. Nominalnie jego wielkość wzrosła z około 53 mld zł w 1990 roku do ponad 273 mld zł w 1999 roku. Wysoka dynamika (około pięciokrotny wzrost) nie przełożyła się na wzrost wskaźnika relacji długu publicznego do PKB. W tym wypadku obserwowano odmienną sytuację. Biorąc pod uwagę ten wskaźnik w latach 1990-1999, nastapił spadek wielkości długu publicznego z poziomu blisko 95\% na początku analizowanego okresu do około 41\% w 1999 roku.

TABELA 1.

Dług publiczny w Polsce w latach 1990-1999 (wartość w mld PLN) i w relacji do PKB (wartość w \%)

\begin{tabular}{|l|c|c|c|c|c|c|c|c|c|c|}
\hline Wyszczególnienie & $\mathbf{1 9 9 0}$ & $\mathbf{1 9 9 1}$ & $\mathbf{1 9 9 2}$ & $\mathbf{1 9 9 3}$ & $\mathbf{1 9 9 4}$ & $\mathbf{1 9 9 5}$ & $\mathbf{1 9 9 6}$ & $\mathbf{1 9 9 7}$ & $\mathbf{1 9 9 8}$ & $\mathbf{1 9 9 9}$ \\
\hline $\begin{array}{l}\text { Dług publiczny } \\
\text { (mld PLN) }\end{array}$ & 53,2 & 65,8 & 97,9 & 138,1 & 152,2 & 167,3 & 185,6 & 221,6 & 237,4 & 273,4 \\
\hline $\begin{array}{l}\text { Dług publiczny } \\
\text { w relacji do PKB } \\
(\%)\end{array}$ & 94,9 & 81,3 & 85,2 & 88,6 & 67,6 & 49,6 & 43,9 & 43,0 & 39,5 & 41,1 \\
\hline
\end{tabular}

Źródło: opracowano na podstawie: [Sprawozdania z. nyłkonania budżętu państwa..., 1990-1999].

Można przyjąć, że nominalny wzrost długu publicznego w Polsce był efektem szeroko rozumianego procesu budowy gospodarki rynkowej, zwiazanego z szeregiem reform gospodarczych, które doprowadziły do wejścia naszego kraju na trwałą ścieżkę rozwoju 
gospodarczego. Z kolei relacja długu publicznego do PKB wskazuje na wysoki poziom wzrostu gospodarczego w Polsce w ostatniej dekadzie XX wieku.

Od 2000 roku, kiedy nastapiły zmiany w kwestii liczenia długu publicznego (ewidencjonowanie będące wynikiem niezbilansowanych budżetów: rządowego i samorządowego), mamy do czynienia z jego większym wzrostem. Wielkość długu publicznego w latach 2000-2013 obrazują dane zawarte w tabeli 2. W analizowanym okresie dług publiczny wzrósł ponad trzykrotnie z 288 mld PLN w 2000 roku do 945 mld PLN w 2013 roku, przy czym największy wzrost odnotowano w latach 2007-2011 (z 537 do 861 mld PLN). Biorąc pod uwage relację długu publicznego do PKB, jego wielkość wzrosła z 37,7\% w 2000 roku do blisko 54\% w 2013 roku.

TABELA 2.

Dług publiczny w Polsce w latach 2000-2013 (wartość w mld PLN) i w relacji do $\mathrm{PKB}$ (wartość w \%)

\begin{tabular}{|l|r|r|r|r|r|r|r|r|r|r|r|r|r|r|}
\hline $\begin{array}{c}\text { Wyszczegól- } \\
\text { nienie }\end{array}$ & $\mathbf{2 0 0 0}$ & $\mathbf{2 0 0 1}$ & $\mathbf{2 0 0 2}$ & $\mathbf{2 0 0 3}$ & $\mathbf{2 0 0 4}$ & $\mathbf{2 0 0 5}$ & $\mathbf{2 0 0 6}$ & $\mathbf{2 0 0 7}$ & $\mathbf{2 0 0 8}$ & $\mathbf{2 0 0 9}$ & $\mathbf{2 0 1 0}$ & $\mathbf{2 0 1 1}$ & $\mathbf{2 0 1 2}$ & $\mathbf{2 0 1 3}$ \\
\hline $\begin{array}{l}\text { Dług publicz- } \\
\text { ny (mld PLN) }\end{array}$ & 288 & 314 & 365 & 415 & 440 & 477 & 518 & 537 & 609 & 693 & 778 & 861 & 889 & 945 \\
\hline $\begin{array}{l}\text { Dług publicz- } \\
\text { ny w relacji do } \\
\text { PKB (\%) }\end{array}$ & 37,7 & 38,8 & 43,6 & 48,4 & 46,7 & 47,5 & 47,8 & 44,8 & 46,9 & 49,8 & 52,8 & 53,4 & 52,7 & 53,9 \\
\hline
\end{tabular}

Źródło: opracowano na podstawie: [Sprawozdania z. uykkonania budżetu państwa..., 2000-2013].

W przygotowywanych przez Ministerstwo Finansów „Strategiach zarządzania długiem sektora finansów publicznych" można przeczytać, że w latach 2000-2013 wzrost długu publicznego w ujęciu nominalnym był wypadkową stosunkowo wysokich potrzeb pożyczkowych budżetu państwa, malejących wpływów z prywatyzacji oraz zmian kursu złotego, a od 2011 roku również konsolidacji zarządzania płynnością sektora finansów publicznych. Wysokie tempo wzrostu gospodarczego i poprawa sytuacji finansów publicznych w latach 2004-2006 wpłynęły na stabilizację relacji długu publicznego do PKB (średnio na poziomie około 47\%). Z kolei w 2007 roku znaczne umocnienie złotego spowodowało nawet przejściowy spadek relacji poniżej 45\% PKB. W latach 2008-2013 nastapił ponowny wzrost relacji długu publicznego do PKB, głównie w wyniku silnego wzrostu potrzeb pożyczkowych sektora finansów publicznych oraz obniżenia tempa wzrostu gospodarczego (m.in. na skutek światowego kryzysu finansowego), [m.in. Strategia zarzqdzania..., 2011, s. 6; Strategia zarzqdzania..., 2014, s. 7].

W związku z coraz większym przyrostem długu publicznego w Polsce pojawia się pytanie: jakie działania należy przeprowadzić, aby ograniczyć jego wzrost. Mogą służyć temu właściwe rozwiązania instytucjonalne.

\section{Instytucjonalne instrumenty ograniczania długu publicznego}

Instytucje, rozumiane jako reguły gry lub zestaw stabilnych reguł, tworzą podstawowe struktury, w ramach których społeczeństwa budują ład pozwalający na zmniejszenie 
niepewności w procesie gospodarowania ${ }^{2}$. W sferze finansów publicznych takie standardy ustanawia m.in. polityka fiskalna.

Polityka fiskalna stanowi zasadnicze narzędzie polityki gospodarczej. W zależności od sposobu posługiwania się określonymi instrumentami można wyróżnić politykę fiskalną: pasywną oraz aktywną. W odpowiedzi na pogarszającą się sytuację gospodarcza, a także wzrost zadłużenia wielu krajów europejskich, niektóre państwa podjęły działania mające za zadanie wzmocnienie polityki fiskalnej przez wprowadzenie norm prawnych wspomagających działania rządów w zakresie prowadzenia odpowiedzialnej, zrównoważonej i transparentnej polityki fiskalnej. Ogół rozwiązań legislacyjnych, podjętych w celu wprowadzenia opisywanych rozwiązań określa się mianem odpowiedzialnej polityki fiskalnej (FRL - fiscal responsibility laws), [Dziemianowicz, 2011, s. 12-14].

Do instrumentów odpowiedzialnej polityki fiskalnej zalicza się:

- procedury budżetowe (legislacyjne reguły fiskalne),

- reguły fiskalne (numeryczne),

- niezależne instytucje fiskalne monitorujące i kontrolujące politykę fiskalna.

Istotny wpływ na realizowaną w Polsce politykę fiskalną (zwłaszcza na jej przejrzystość) wywieraja procedury budżetowe. Sa to formalne i nieformalne regulacje rządzące decyzjami legislacyjnymi w postaci reguł dotyczących: przygotowania budżetu, jego uchwalania i wdrażania. Tego rodzaju instytucje sa jednym $z$ najważniejszych narzędzi FRL, ponieważ umożliwiają ograniczenie skali wydatków publicznych oraz nierównowagi budżetowej. W literaturze przyjmuje się, że im bardziej scentralizowane procedury budżetowe, tym mniejsza skłonność władzy do prowadzenia ,luźnej” polityki budżetowej. Zastosowanie właściwych rozwiązań w tym zakresie powinno przyczynić się do ograniczenia nierównowagi fiskalnej [Perotti, Kontopoulos, 2002; Debrun, Hauner, Kumar, 2009].

Ze względu na zjawisko nazywane w literaturze „problemem wspólnej puli zasobów”, M. Hallerberg i J. von Hagen wskazuja na potrzebę centralizacji procesu budżetowego. Według nich, przy tworzeniu budżetu powinien obowiązywać tzw. kontrakt fiskalny. Cele fiskalne i limity dotyczące różnych kategorii wydatków publicznych powinny być jasno sformułowane i uzgodnione w dłuższej perspektywie bądź minister finansów powinien zostać wyposażony w odpowiednie narzędzia pozwalające na właściwe administrowanie i zarządzanie budżetem, umożliwiające egzekwowanie planu finansowego państwa (delegowanie uprawnień), [Hallerberg, von Hagen, 2006, s. 46-52].

Innym, obecnym w Polsce, ważnym narzędziem odpowiedzialnej polityki fiskalnej sa reguły fiskalne. Można je definiować jako długotrwałe ograniczenia polityki fiskalnej, wyrażone wskaźnikami wprowadzającymi limit dla określonego agregatu fiskalnego (deficytu budżetowego lub długu publicznego) zazwyczaj w odniesieniu do PKB. Reguky fiskalne są instrumentem mającym wspomagać realizację przejrzystej polityki fiskalnej [Dziemianowicz, 2011, s. 17].

Reguły fiskalne powinny mieć ściśle określony charakter aby móc spełniać swoją rolę, Według Kopits i Symansky muszą być:

\footnotetext{
${ }^{2}$ Szerzej na temat pojęcia instytucji zobacz m.in. w: [North, 1990; Ménard, 1995].
} 
- precyzyjnie zdefiniowane, by uniknąć niejasności i nieskuteczności w egzekwowaniu; reguły powinny być dokładnie określone, nie tylko co do limitu wskaźnika, ale także co do ich instytucjonalnego zasięgu oraz klauzul niepozwalajacych na ich obejście;

- transparentne, jawne pod względem rachunkowym, lecz również w zakresie prognozowania i zarządzania;

- proste, zrozumiałe zarówno dla ustawodawcy, jak i społeczeństwa;

- elastyczne, umożliwiające reakcję w sytuacji wystapienia szoków asymetrycznych, jednak zarazem zawierające klauzule wyjścia;

- adekwatne, odpowiednie do realizowanego celu;

- egzekwowalne, ustanowione aktami prawnymi wyższej rangi (konstytucja, ustawy), które zawieraja jednocześnie właściwie zdefiniowane sankcje za nieprzestrzeganie reguł i zasady ich egzekwowania;

- spójne, zgodne z przyjętą średnio- i długoterminową strategią fiskalną i polityką gospodarcza;

- efektywne, wspierane przez skuteczne działania polityczne [Kopits, Symansky, 1998, s. 18-19].

Przytoczone wyżej cechy, charakteryzujące ,idealne reguły fiskalne”, są w głównej mierze punktem odniesienia, do którego powinno się dążyć przy ich tworzeniu. Niemniej trudno faktycznie znaleźć reguły fiskalne, które skonstruowano na podstawie tego wzorca [Dziemianowicz, 2011, s. 16-17].

$\mathrm{Na}$ poziomie europejskim reguly fiskalne funkcjonuja w postaci unormowań z Traktu z. Maastricht z dnia 7 lutego 1992 roku (Dz. U. C 191 z 29.7.1992). Wyznaczają one maksymalny poziom długu publicznego na poziomie $60 \%$ PKB. Jednak ograniczenia te nie są przestrzegane przez większość krajów Unii Europejskiej, gdyż Traktat ani inne dokumenty stanowiące podstawy funkcjonowania Unii Europejskiej nie przewiduja realnych sankcji za przekroczenie progu 60\% PKB. Z kolei w Polsce działanie reguł fiskalnych odbywa się na podstawie dwóch aktów prawnych: Konstytucji Ræ̌eçypospolitej Polskiej z dnia 2 kwietnia 1997 roku (Dz. U. Nr 78, poz. 483) oraz Ustany z. dnia 27 sierpnia 2009 roku o finansach publicznych (Dz. U. Nr 157, poz. 1240 z późniejszymi zmianami). Według Ustany zasadniczej, dług publiczny nie może przekraczać 3/5 wartości rocznego PKB. Natomiast zgodnie z Ustawa o finansach publicznych, należy podejmować określone działania ostrożnościowe i sanacyjne, gdy stosunek łącznej kwoty państwowego długu publicznego, powiększonej o kwotę przewidywanych wypłat $z$ tytułu poręczeń i gwarancji udzielonych przez podmioty sektora finansów publicznych, do PKB będzie kształtował się w przedziale $55-60 \%$ PKB. W przypadku przekroczenia górnego limitu zadłużenia (55\% lub 60\% wartości rocznego PKB) jest przewidziane zastosowanie odpowiednich procedur bezpieczeństwa mających na celu ograniczenie poziomu długu³.

3 Warto podkreślić, że na mocy Ustany z dnia 26 lipca 2013 roku o zmianie ustany o finansach publiczmych (Dz. U. 2013, poz. 938) polski ustawodawca dokonał zawieszenia stosowania przepisów regulujących tzw. I procedurę ostrożnościowa (dług publiczny na poziomie 50\% PKB) do końca 2013 roku. Tymczasem dokonane zmiany legislacyjne miały miejsce również w 2014 roku. Jest tak dlatego, że mechanizmy ograniczające wzrost deficytu i wydatków budżetu państwa odnosily się do procesu konstruowania projektu budżetu państwa na kolejny 
Wydaje się, że reguły fiskalne są skutecznym narzędziem ograniczającym skłonność rządzących do generowania nadmiernych deficytów. Jednak nie wystarczy samo ich wprowadzenie, by spełniały swoją korygująca funkcję. Skuteczne reguły fiskalne muszą być wiarygodne. Powinny obejmować cały sektor finansów publicznych, zawierać mechanizmy monitoringu oraz procedury egzekucyjne. Efektywność reguł zwiększa się, gdy są one sformalizowane, czyli posiadają umocowanie w ustawie bądź konstytucji [Dziemianowicz, Kargol-Wasiluk, 2014, s. 226-227].

Nie mniej ważnym narzędziem odpowiedzialnej polityki fiskalnej (niestety nie istniejącym w Polsce) jest tzw. rada fiskalna (w literaturze funkcjonuje również pojęcie niezależnej instytucji fiskalnej). Celem takiej instytucji jest przede wszystkim monitorowanie bieżącej polityki fiskalnej oraz ocenianie jej prowadzenia w długim okresie, a także kontrolowanie długu publicznego. W wielu krajach, na których Polska może wzorować się, takie instytucje już funkcjonuja (tabela 3.).

\section{Rady fiskalne w krajach Unii Europejskiej}

\begin{tabular}{|c|c|c|}
\hline Kraj & Nazwa & Rok powołania \\
\hline Austria & Government Debt Comittee & 1997 \\
Belgia & Public Sector Borrowing Requirement - Section of the & 1989 \\
& High Council of Finance & \\
Chorwacja & Fiscal Policy Council & 2013 \\
Dania & Economic Council & 1962 \\
Finlandia & National Audit Office of Finland & 2013 \\
Francja & High Council of Public Finance & 2013 \\
Holandia & Central Planning Bureau & 1945 \\
Irlandia & Fiscal Advisory Council & 2011 \\
Niemcy & Council of Economic Experts & 1963 \\
Portugalia & Portuguese Public Finance Council & 2011 \\
Rumunia & Fiscal Council & 2010 \\
Słowacja & Council for Budget Responsibility & 2012 \\
Słowenia & Fiscal Council & 2010 \\
Szwecja & Fiscal Policy Council & 2007 \\
Wegry & Fiscal Council & 2009 \\
Wielka Brytania & Office for Budget Responsibility & 2010 \\
Włochy & Parliamentary Budget Office & 2014 \\
\hline
\end{tabular}

Źródło: [Dziemianowicz, Kargol-Wasiluk, 2012].

Istnieją różne formy, w ramach których powinny być organizowane rady fiskalne. Gołębiowski proponuje trzy modele:

- model bardzo miękki (,very soff') - rady spełniają funkcję opiniotwórcza, przygotowuja niezależne i fakultatywne opinie eksperckie (przykładem takiej instytucji jest m.in. German Council of Academic Experts w Niemczech);

rok budżetowy. W rezultacie minister finansów oraz Rada Ministrów, przygotowując projekt budżetu na rok 2014, nie byly związane restrykcjami wynikającym z ustawy. Z kolei na mocy Ustany z dnia 8 listopada 2013 roku o zmianie ustany ofinansach publicznych oraz niektórych innych ustaw (Dz. U. 2013, poz. 1646) I procedura ostrożnościowa została zniesiona w ogóle. Szerzej: [Tyniewicki, 2014]. 
- model miękki („,soff') - rady odgrywają tutaj rolę doradcza, prognostyczną i opiniotwórczą (np.: Danish Economic Council w Dani, High Council of Finance w Belgii oraz The Swedish Fiscal Policy Council w Szwecji);

- model twardy (,,hard') - rady ustalają co roku poziom salda budżetowego oraz oczekiwany poziom długu publicznego (obecnie nie funkcjonuje na świecie instytucja, która spełniałaby opisywane kryteria), [Gołębiowski, 2010, s. 3-4].

Z kolei Debrun, Hauner i Kumar wyodrębniają dwa teoretyczne modele niezależnych organów fiskalnych. Różnią się one przede wszystkim zakresem zadań i poziomem kompetencjit:

- $\quad$ niezależne instytucje fiskalne (Independent Fiscal Authorities) - instytucje, które ustalają coroczne cele dla salda budżetu państwa i poziom długu publicznego lub określają reguły fiskalne, dostosowują poziom podatków i wydatków publicznych;

- $\quad$ rady fiskalne (Fiscal Councils) - instytucje, które mają za zadanie wpływać na kształt polityki fiskalnej przez niezależne analizy, prognozy i doradztwo [Debrun, Hauner, Kumar, 2009, s. 57].

Niezależne instytucje fiskalne (NIF) są wzorowane na radach polityki pieniężnej, które opiniują i wspomagaja realizowana przez władzę wykonawcza politykę fiskalna. Jednym z głównych powodów przemawiających za utworzeniem NIF, zwłaszcza w Polsce, jest potrzeba obniżenia poziomu długu publicznego, chęć ograniczenia wpływu tzw. cyklu wyborczego na decyzje polityków oraz dążenie do poprawy jakości polityki fiskalnej, a w szczególności ograniczenie jej uznaniowości i procykliczności, a także zwiększenie transparentności. Niezależne instytucje fiskalne zgodnie z umocowaniem w aktach normatywnych oraz zakresem kompetencji mogą realizować następujące zadania: dokonywać oceny funkcjonowania sektora finansów publicznych, polityki fiskalnej oraz jej makroekonomicznego kontekstu; oceniać przejrzystość ustawy budżetowej oraz jej zgodność z priorytetami polityki gospodarczej; opracowywać niezależne, długookresowe prognozy makroekonomiczne w odniesieniu do różnych wariantów polityki fiskalnej; formułować rekomendacje dla rządu. Naczelnym celem działania rad fiskalnych jest ograniczenie ryzyka związanego z prowadzeniem nieodpowiedzialnej polityki fiskalnej, a przede wszystkim jej monitorowanie, kontrolowanie deficytu i długu publicznego oraz ocena długookresowych skutków działań podejmowanych przez rząd w tym zakresie. Warto podkreślić, że powołanie NIF nie oznacza bezwarunkowej i szybkiej poprawy dyscypliny budżetowej [por.: Dziemianowicz, Kargol-Wasiluk, 2012, s. 42-43; Dziemianowicz, Kargol-Wasiluk, 2014, s. 226-227].

\section{Podsumowanie}

Podstawowym problemem polskich finansów publicznych jest systematyczne zwiększanie się długu publicznego. Co gorsza, najprawdopodobniej dług na tak wysokim po-

\footnotetext{
${ }^{4}$ Taką typologię niezależnych organów fiskalnych również preferuje R. Hagemann [Hagemann, 2010, s. 9].
} 
ziomie będzie utrzymywał się w najbliższych latach. Wysokie oraz narastające zadłużenie pociaga za sobą konieczność działań konsolidacyjnych ze względu na ograniczenia wynikające $z$ ustawodawstwa krajowego, jak i przepisów Unii Europejskiej. Perspektywa zwiększania się poziomu długu publicznego wywołuje potrzebę instytucjonalnego wzmocnienia ram prowadzania polityki fiskalnej. Odpowiedzialna polityka fiskalna (w Polsce funkcjonuja procedury budżetowe i reguły fiskalne) jest odpowiedzią na rosnący poziom długu i może być skutecznym sposobem na jego obniżenie. Nie oznacza to, że ustanowienie regulacji prawnych w postaci procedur budżetowych, reguł fiskalnych bądź niezależnej instytucji fiskalnej ${ }^{5}$ rozwiążą wszystkie problemy związane z brakiem odpowiedzialności w polityce fiskalnej. Niewątpliwie może jednak przyczynić się do wzrostu jej efektywności i transparentności.

\section{Literatura}

Chojna-Duch E. 2012 Podstawy finansów publicznych i prawa finansowego, Wydawnictwo Prawnicze LexisNexis, Warszawa.

Debrun X., Hauner D., Kumar M. S. 2009 Independent fiscal agencies, „Journal of Economic Surveys", vol. 23.

Dziemianowicz R. I. 2011 Reguly fiskalne i ich wplyw na ograniczenie dlugu publicznego, „Zeszyty Naukowe Wyższej Szkoły Bankowej w Poznaniu”, nr 37.

Dziemianowicz R. I., Kargol-Wasiluk A. 2012 Instytucjonalne ramy odpowiedzialnej polityki fiskalnej, [w:] Stabilizacja fiskalna: teorie i doswriadczenia wybranych gospodarek, D. Miłaszewicz (red.), Przedsiębiorstwo Produkcyjno-Handlowe ZAPOL Dmochowski, Sobczyk, Szczecin.

Dziemianowicz R. I., Kargol-Wasiluk A. 2014 Fiscal Responsibility Laws in the EU Member States and their influence on the stability of the public finance, [in:] International Congress on Economy, Finance, and Business, vol. II, Conference Organizers International Academy Institute National Taipei University International Business Academics Consortium (iBAC).

Encyklopedia PWN, dokument elektroniczny, tryb dostępu: [http://encyklopedia.pwn.pl/ szukaj/d\%C5\%82ug-publiczny.html, data wejścia: 24.10.2014].

Gajewski P., Skiba L. 2010 Problemy politykei fiskalnej Polski na drodze do strefy euro w kontekśsie uwarunkowań i doswiadczeń innych państw, NBP - Biuro ds. Integracji ze Strefą Euro, Warszawa.

Gołębiowski G. 2010 Rada polityki fiskalnej, „Infos BAS”, nr 7(79).

Hagemann R. 2010 Improving Fiscal Performance Through Fiscal Councils, OECD Economics Department Working Papers, no. 829.

Hallerberg M., von Hagen J. 2006 Organizacja procesu budżetowego w Polsce. Reguly budżetowe a stabilność fiskalna i gospodarcza, Ernst\&Young, Warszawa.

${ }^{5} \mathrm{~W}$ Polsce wartym rozważenia rozwiązaniem jest powołanie jednej z brakujących instytucji FRL - rady fiskalnej. Pełniłaby ona funkcję zewnętrznego recenzenta ustaw budżetowych konstruowanych w naszym kraju oraz ich zgodności z wieloletnimi planami finansowymi państwa, por.: [Grajewski, Skiba, 2010, s. 98]. 
Konstytucja z dnia 2 kwietnia 1997 roku Rzeçypospolitej Polskiej, Dz. U. z 2009 roku, Nr 78, poz. 483.

Kopits G., Symansky S. 1998 Fiscal policy rules, International Monetary Fund, Occasional, Paper, no. 162, Washington.

McConnell C. R., Brue S. L., Flynn S. M. 2009 Economics: Principles, Problems, and Policies, McGraw-Hill/Irwin, New York.

Ménard C. 1995 Markets as Institutions vs Organizations as Markets: Disentangling Some Fundamental Concepts, „Journal of Economic Behavior and Organizations”, vol. 28, no. 3.

North D. C. 2009 Institutions Institutional Change and Economic Performance, Cambridge University Press, Cambridge.

Owsiak S. 2013 Finanse publiczne teoria i praktyka, Wydawnictwo Naukowe PWN, Warszawa.

Perotti R., Kontopoulos Y. 2002 Fragmented fiscal policy, „Journal of Public Economics 86".

Poniatowicz M. 2005 Dtug publiczny w systemie finansonym jednostek samorzadu terytorialnego, Wydawnictwo Uniwersytetu w Białymstoku, Białystok.

Rosporzadzenie Rady (WE) nr 2223/96 ₹ 25 czervica 1996 roku w sprawie europejskiego systemu rachunków narodonych i regionalnych we $W$ spólnocie.

Rosporzadzenie Rady (WE) nr 3605/93 ₹ 22 listopada 1993 roku w sprawie stosowania protokotu w sprawie procedury dla nadmiernego deficytu, załączonego do Traktatu ustanawiającego Wspólnotę Europejską.

Samuelson P. A. Nordhaus W. D. 1997 Ekonomia 1, Wydawnictwo Naukowe PWN, Warszawa.

Samuelson P. A. Nordhaus W. D. 2012 Ekonomia, Dom Wydawniczy REBIS, Poznań.

Sprawozdania z.uykeonania budżetu państwa w latach 1990-2013, dokument elektroniczny, tryb dostępu: [www.mf.gov.pl, data wejścia: 14.07.2014].

Strategia zarzadzania dtugiem sektora finansón publicznych w latach 2012-2015 2011, Ministerstwo Finansów, Warszawa.

Strategia zarzadzania dtugiem sektora finansów publicznych w latach 2015-2018 2014, Ministerstwo Finansów, Warszawa.

Traktat o Unii Europejskiej z dnia 7 lutego 1992 roku, Dz. U. C 191 z 29.7.1992.

Tyniewicki M. 2014 Prawna ocena wytaczenia obowiazywania I progu ostrożnościowego w ustawie o finansach publicznych, „Prawo Budżetowe Państwa i Samorządu”, nr 1(2).

Ustawa z. dnia 26 lipca 2013 roku o zmianie ustany o finansach publicznych, Dz. U. z 2013 roku, poz. 938.

Ustawa z dnia 27 sierpnia 2009 roku o finansach publicznych, Dz. U. z 2009 roku, Nr 157, poz. 1240 z późniejszymi zmianami.

Ustawa z dnia 8 listopada 2013 roku o zmianie ustany o finansach publicznych oraz niektórych innych ustaw, Dz. U. z 2013 roku, poz. 1646.

Wernik A. 2014 Finanse publicæne, Polskie Wydawnictwo Ekonomiczne, Warszawa. 